\title{
Molecular analysis of the regulation of nisin immunity
}

\author{
H. M. Dodd, ${ }^{1}$ N. Horn, ${ }^{1}$ W. C. Chan ${ }^{2}$ C. J. Giffard ${ }^{3}{ }^{3}$ B. W. Bycroft, ${ }^{2}$ \\ G. C. K. Roberts ${ }^{4}$ and M. J. Gasson ${ }^{1}$
}

Author for correspondence: H. M. Dodd. Tel: +44 1603 255243. Fax: +44 1603507723. e-mail: DODDH@BBSRC.AC.UK

1 Department of Genetics and Microbiology, Institute of Food Research, Norwich Research Park, Colney, Norwich NR4 7UA, UK

2 Department of Pharmaceutical Sciences, University of Nottingham, University Park, Nottingham NG7 2RD, UK

3 Department of Biology, University of York, York YO1 5DD, UK

4 Department of Biochemistry and Biological NMR Centre, University of Leicester, Leicester, UK

\begin{abstract}
The genetic determinants controlling immunity to nisin are coordinately regulated, along with biosynthesis genes, in response to an environmental signal, nisin or a nisin analogue. The nisR gene product, the putative response regulator of nisin biosynthesis, was found to be a vital component of this induction mechanism. This protein forms part of a two-component regulatory system which controls the expression of genes involved in nisin immunity and biosynthesis. Analysis of the structural requirements of the external signal, using nisin fragments and engineered nisin variants, indicated that the 12 amino-terminal residues of the molecule are a minimum requirement for induction, with an intact ring $A$ being an essential component. Changes throughout the molecule also affected its induction capacity. The production of certain variant nisins by engineered lactococcal strains is reduced in parallel with the strains' immunity to nisin. This can be attributed to inefficient induction by the variant molecule. Treating growing cultures with nisin restored full immunity and maximized the yields of nisin variants by the producer strains.
\end{abstract}

Keywords: nisin, immunity, regulation, induction, Lactococus lactis

\section{INTRODUCTION}

Biosynthesis of the lantibiotic nisin is a complex mechanism requiring the activity of 11 genes (nis ABTCIPRKFEG) clustered together in the Lactococcus lactis genome. It is an inducible system in which the mature nisin molecule provides an external stimulus for expression of nisin-biosynthesis determinants (Kuipers $e t$ al., 1995). The ability of nisin-producing bacteria to control the expression of the biosynthesis genes in response to an envitonmental stimulus involves a twocomponent regulatory system (Wanner, 1992) comprising a membrane-located 'sensor' protein (NisK) that detects the stimulus (Van der Meer et al., 1993; Engelke et al., 1994) and a cytoplasmic response regulator (NisR) that controls transcription from the nis. $A$ promoter (Kuipers et al., 1993), thus facilitating an adaptive response.

In order for cells to produce nisin they must necessarily be immune to this antimicrobial peptide. However, at

\footnotetext{
Abbreviations: Dha, dehydroalanine; Dha5A, dehydroalanine substituted for alanine at position 5; Dha33A, dehydroalanine substituted for alanine at position 33; H27K, lysine substituted for histidine at position 27 ; 130W, tryptophan substituted for isoleucine at position $30 ; \mathrm{K} 12 \mathrm{~L}$, leucine substituted for lysine at position 12.
}

present, the mechanism by which cells overcome the antagonistic effect of nisin is not fully understood. The misI gene product has been implicated as an immunity protein because expression of the cloned gene in a sensitive L. lactis strain confers a degree of immunity on the host cell (Kuipers $e t$ al., 1993; Engelke $e t$ al., 1994; Qiao et al., 1995). The nis $F$, nis $E$ and nis $G$ gene cluster is also thought to play a role in self-immunity to nisin as strains deficient in any of these functions display a greater sensitivity to nisin (Siegers \& Entian, 1995). It has been established that nisin production is linked to nisin immunity. When nisin-producing strains are rendered $\mathrm{Nis}^{-}$by inactivation of the structural gene for pre-nisin (nis $A$ ), the cells are significantly more sensitive to nisin (Dodd et al., 1992; Kuipers et al., 1993). It was observed that the actual level of immunity in different strains varied, depending on the type of mutation suffered by the nis $A$ gene. This prompted an investigation into how induction affects the levels of immunity to nisin in different strains. Evidence is presented which indicates that immunity can be recovered by exposing cells to subinhibitory levels of nisin or nisin analogues. The in volvement of the sensor histidine kinase (NisK) in the autoregulation of nisin biosynthesis has been reported (Kuipers et al., 1995). Here, we demonstrate that the 
response regulator (NisR protein) is essential for induction of immunity, consistent with the proposal that the two-component regulatory system is integral to the control of exptession of the nisin operon.

An analysis of the structural requirements of the inducing agent was undertaken involving a number of enzymically generated nisin fragments and engineered nisin variants. Nisin immunity was employed as a measure of the effectiveness of induction of the various analogues. 'The results indicate that the molecular interactions that occur between the external stimuli and NisK require specific parts of the nisin molecule for efficient induction of nisin biosynthesis and immunity.

In the course of studies involving the protein engineering of nisin (Dodd et al., 1992, 1996), it was observed that, in a number of cases, strains producing variant nisin molecules displayed lower levels of immunity than the parent strain FI5876. The genetic linkage of nisin immunity to nisin production is effectively illustrated using engineered strains that produce vatiant nisins at reduced levels. By inducing full immunity it proved possible to optimize these expression systems, enabling maximum production levels of a variant nisin.

\section{METHODS}

Bacterial strains. All strains used in this study are derivatives of the nisin-producing strain Lattococcus lactis FI5876 (Dodd et al., 1990). Maps of $\mathrm{Nis}^{-}$derivatives are shown in Fig. 1. In each case, a plasmid-encoded wild-type nis $A$ gene was converted to a defective gene, which was then incorporated into the chromosome using the technique of gene replacement (Dodd $e t$ al., 1996). The construction of FI7300 (Fig. 1b) involved the insertional inactivation of the $n i s . A$ gene by cloning a $1 \mathrm{~kb}$ fragment encoding erythromycin resistance $\left(\mathrm{Em}^{\mathrm{r}}\right)$ into the internal $S_{a c} \mathrm{I}$ site of the nis $A$-coding region (Dodd $e t$ al., 1992). This fragment included a potential tho-independent terminator at the end of the $\mathrm{Em}^{\mathrm{r}}$ gene (Horinouchi \& Weisblum, 1982). In FI7990, the entire nis $A$ gene was deleted as a result of engineering specific restriction enzyme sites on either side of the gene (Dodd et al., 1996). By digesting and re-ligating DNA sequences, a 300 bp sequence including both the coding region and the upstream promoter was deleted (Fig. 1c). FI7847 is detived from FI7300 and carries a 20 bp insertion in nis A, resulting in its inactivation (Fig. 1d). In the gene replacement vector used in the construction of FI7300, the $\mathrm{Em}^{\mathrm{r}}$ gene and terminator signal were deleted by digestion with $S$ maI, followed by re-ligation. Residual sequences from the multiple cloning site which flanked the $\mathrm{Em}^{\mathrm{r}}$ gene leave a $20 \mathrm{bp}$ insertion within the SacI site and cause a frameshift mutation to occur in codon 16 of the nis $A$ gene in FI7847. This would effectively truncate the predicted translation product at the carboxy-terminus. In all these Nis ${ }^{-}$strains, the sequences of the downstream genes have been unaffected by the changes introduced into nis $A$. Generating the NisR ${ }^{-}$strain FI8510 (Fig. 1e) required the construction of a gene teplacement vector from cloned FI5876 sequences extending from the $S_{a l}$ site in nisP to the Bam HI site in $n i s F$, including the $n i s \mathrm{R}$ and nis $K$ genes. Sequences lying berween the EcoRV site, within nisR and the $S_{a l} I$ site, $24 \mathrm{bp}$ from the start of $n i s K$, were deleted and replaced by a synthetic linker. This was generated by annealing the two complementary primers 5'-CT'TGGGTATCAGTGGCATGGGTAAAAAATATTCAATGCG and 5'-TCGACGCATTGAATATT'T'T- (a) F15876

$\begin{array}{lllll}S & H & E & S & B\end{array}$

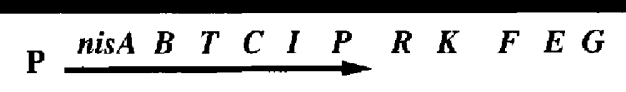

(b) $\mathrm{F} 17300$

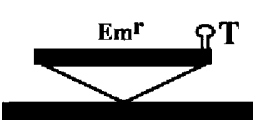

$\begin{array}{lllllllllll}\operatorname{nis} A & B & T & C & I & P\end{array} \quad R \quad K \quad F \quad E G$

$\Delta$

(c) F17990

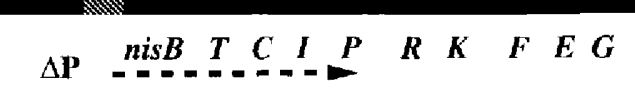

(d) $\mathrm{Fl} 17847$

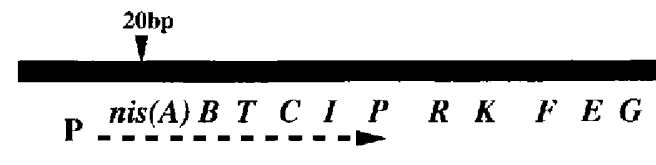

(e) $\mathrm{F} / 8510$

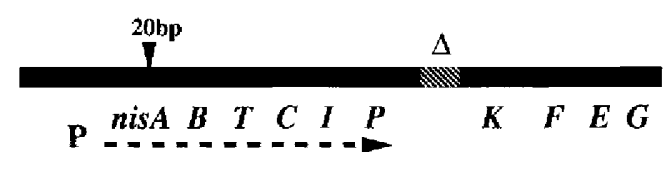

Fig. 1. Maps of the region of $L$. lactis genome showing the relative location of the nisin genes nisABTCIPRKFEG in F15876 (a) and Nis derivatives FI7300 (b), FI7990 (c), FI7847 (d) and FI8510 (e). Mutations generated by insertion of DNA sequences are shown above the maps. The transcription terminator (T), downstream of the $\mathrm{Em}^{\mathrm{r}}$ gene in $\mathrm{FI} 7300$ (b). is represented by a hairpin loop. Deletions in chromosomal sequences $(\Delta)$ are indicated by a hatched region. The location of the inducible promoter upstream of nisA is indicated by $P$, and transcription of the proposed operon nisABTCIP is shown as an arrow below the maps. The broken arrows indicate that transcription may have been affected by the mutation suffered by these strains. Relevant restriction enzyme sites used in the construction of gene replacement vectors are shown above FI5876 (a): S, Sall; $\mathrm{H}$, HindlII; E, EcoRV; B, BamHI.

TACCCATGCCACTGATACCCAAGAGCT, creating a short Sacl-Sall linker containing the start of the nisK gene (underlined). As a result of this linkage of sequences flanking $n i s R$, an intact nisk gene was regenerated including the upstream ribosome-binding site. The final gene replacement vector comprised $1.4 \mathrm{~kb}$ of FI5876 sequences containing the 3 'end of the mis $P$ gene, a deletion of most of the coding region of $n i s \mathrm{R}$ and a $2 \mathrm{~kb}$ downstream region containing a functional $n i s K$ gene. Using the technique of gene replacement (Dodd $e t$ al., 1996), this vector was employed to delete the nisR gene from FI7847, generating the $\mathrm{Nis}^{-} \mathrm{NisR}^{-}$strain F18510 (Fig. 1e).

The adaptation of $L$. lactis FI5876 to express engineered nis $A$ genes has been described previously (Dodd et al, 1996). In strains FI8327, FI8256, FI8278 and FI8290, the genes nis A/ $H 27 \mathrm{~K}$, nis $A / \mathrm{K} 12 \mathrm{~L}$, nis $A / 130 \mathrm{~W}$ and $n i s A / \Delta 21 \mathrm{M}$, respectively, have been incorporated into the genome of FI5876 in place of the wild-type nis $A$ gene.

Construction of pFI1002. The nisR gene of FI5876 was isolated from a AEMBL3 genomic library (Dodd et al., 1990) on a HindIII-SaII fragment and cloned into the lactococcal shuttle vector p'TG262 (Transgene), generating plasmid pFI1002. The cloned $1.13 \mathrm{~kb}$ fragment extends from the end of the nis $P$ gene to the start of the nisK gene and includes the transcription 
signals upstream of nisR. The molecular techniques used in these constructions were performed as described previousiy (Dodd et al., 1996).

Microbiological techniques. Cultures were grown in M17 medium ('Terzaghi \& Sandine, 1975) supplemented with 0.5\% (w/v) glucose (GM17 medium). Incubations were at $30^{\circ} \mathrm{C}$, unless carrying out the gene replacement protocol, in which case culcures were grown at either $28^{\circ} \mathrm{C}$ or $37^{\circ} \mathrm{C}$ (Dodd et al., 1996). Screening strains for resistance to antibiotics was carried out at the following levels: erythromycin $\left(\mathrm{Em}^{\mathrm{r}}\right), 5 \mu \mathrm{g} \mathrm{ml}^{-1}$; streptomycin $\left(\mathrm{Sm}^{\mathrm{r}}\right), 200 \mu \mathrm{g} \mathrm{ml}^{-1}$.

Escbericbia coli MC1022 (Casadaban \& Cohen, 1980) was the host strain for construction of gene replacement vectors derived from the temperature-sensitive replicon $\mathrm{pG}^{+}$host6 (Appligene). Cultures were propagated at $37^{\circ} \mathrm{C}$ in $\mathrm{L}$ broth (Lennox, 1955). Selection for $\mathrm{pG}^{+}$host6-encoded $\mathrm{Em}^{\mathrm{r}}$ and ampicillin resistance $\left(A p^{r}\right)$ was carried out at $400 \mu \mathrm{g} \mathrm{m}^{-1}$ and at $200 \mu \mathrm{g} \mathrm{ml}^{-1}$, respectively.

Nisin assays. Bioassays for production of nisin, or nisin variants, were based on the plate diffusion assay of Tramer \& Fowier (1964) and were performed as described previously (Dodd $e t a l$., 1996). An indication of the degree of immunity to nisin was obtained from streaking or spotting ( $3 \mu$ aliquots) cultures onto the surface of a series of GM17 agar plates containing nisin at increasing concentrations. Immunity was taken as the lowest concentration of nisin at which growth was unaffected after $48 \mathrm{~h}$ incubation. Immunity assays in broth were carried out in sterile cuvettes containing GM17 broth inoculated with stationary phase cultures (1 in 500 dilution). Nisin, or nisin variant, at various concentrations, was added to the cuvettes and growth at $30^{\circ} \mathrm{C}$ was monitored hourly $\left(\mathrm{OD}_{600}\right.$; UVIKON 860 spectrophotometer). In microtitre plate assays, the wells (in triplicate), containing $200 \mu \mathrm{l} \mathrm{GM} 17$ broth, were inoculated with stationary phase cultures ( 1 in 200 dilution). Nisin, or nisin variant, was added and growth at $30^{\circ} \mathrm{C}$ was monitored $\left(\mathrm{OD}_{630}\right)$ on an automated microtitre plate reader (Dynotech). The amount of growth in each sample was determined at the time when the parent strain, in the absence of added nisin, had reached maximum cell density, usually at $t=6-7 \mathrm{~h}$.

Construction of nisin variants. Protein-engineered nisins were generated and purified using the expression system described previously (Dodd et al., 1996). Enzymically generated nisin fragments were produced by digesting nisin with trypsin (nisin ${ }_{1-12}$ ) or $\alpha$-chymotrypsin $\left(\right.$ nisin $_{1-20}$ ) (Chan, et al.,1996). Treatment of nisin with $\mathrm{HCl}$ in glacial acetic acid generated (des$\Delta$ Ala5)nisin (Chan et al., 1989). The 23 amino acid pre-nisin leader sequence was synthesized on an automated peptide synthesizer (Pepsynthesizer 9050; Millipore).

\section{RESULTS}

\section{L. lactis F17847 - induction of immunity to nisin}

Insertional inactivation of the nis $A$ gene in strain FI7847 not only rendered this strain $\mathrm{Nis}^{-}$but also resulted in a significant reduction in its level of self-immunity to nisin. In plate assays, FI7847 displayed approximately $50 \%$ of the immunity levels of the $\mathrm{Nis}^{+}$parent strain FI5876 (no growth detectable above nisin concentrations of $20 \mu \mathrm{g} \mathrm{ml}^{-1}$ ). The capacity to recover wild-type levels of immunity in F17847 was investigated by exposing growing cells to low levels of nisin prior to assaying for immunity in broth. When cultures were incubated overnight in the presence of subinhibitory levels of nisin (100 $\mathrm{ng} \mathrm{ml}^{-1}$ ), immunity was significantiy increased and,
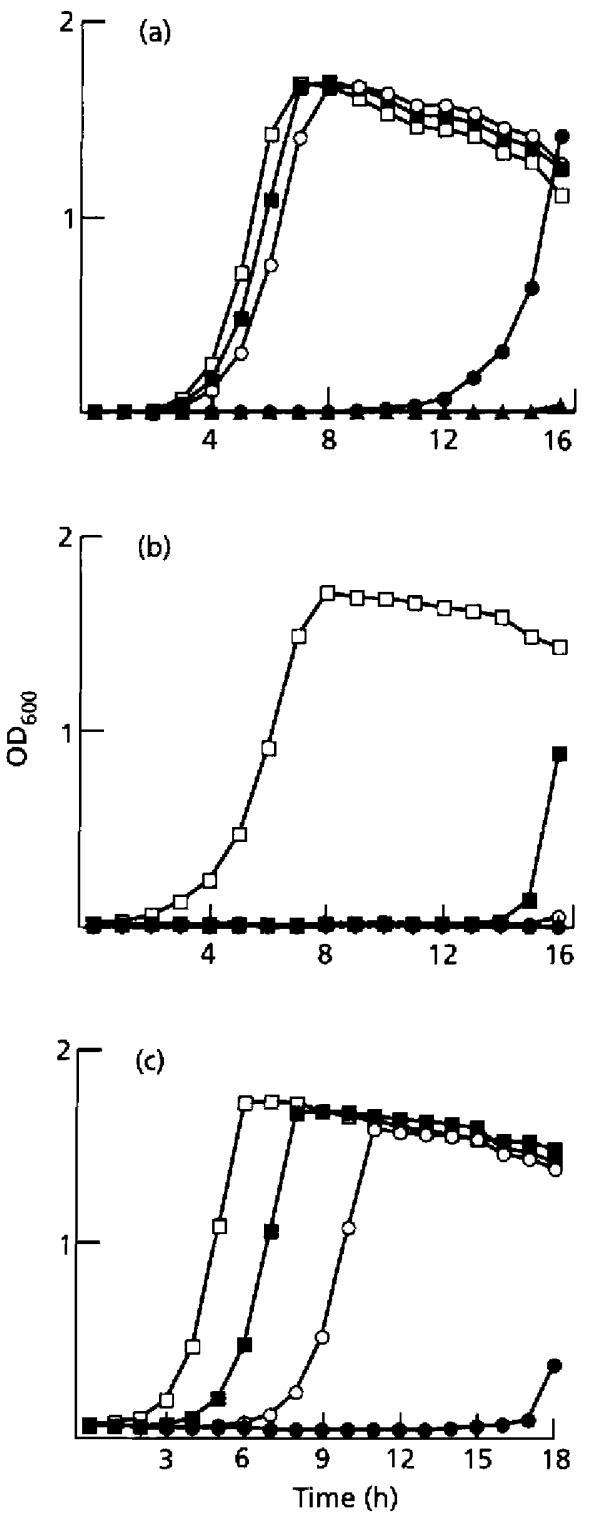

Fig. 2. Immunity to nisin. Cultures were assayed for nisin immunity by determining the effect of nisin on growth in broth containing nisin at the following concentrations: $0(\square)$, $2 \mu \mathrm{g} \mathrm{ml}^{-1}(\mathbf{D}), 5 \mu \mathrm{g} \mathrm{ml}^{-1}(\mathrm{O}), 10 \mu \mathrm{g} \mathrm{ml}^{-1}$ (O) and $20 \mu \mathrm{g} \mathrm{ml}^{-1}$ (A). $\mathrm{OD}_{600}$ readings were taken hourly for cultures of (a) FI5876, (b) FI7847 and (c) Fl7847 that had previously been grown overnight in the presence of $100 \mathrm{ng}$ nisin $\mathrm{ml}^{-1}$.

in contrast to untreated FI7847 (Fig. 2b), cells challenged with up to $5 \mu \mathrm{g}$ nisin $\mathrm{ml}^{-1}$ grew well (Fig. 2c). The addition of nisin to the growth media had the effect of slightly increasing the lag phase when compared to that of FI5876 (Fig. 2a). Therefore, preincubating FI7847 with subinhibitory levels of nisin induces immunity to a level approaching that of the $\mathrm{Nis}^{+}$parent strain FI5876. This response was found to be dependent on the amount of nisin that the cells were exposed to, prior to assaying for immunity. Treating growing cells with $1 \mathrm{ng} \mathrm{ml^{-1 }}$ did not induce immunity. A concentration of $10 \mathrm{ng} \mathrm{ml}^{-1}$ was sufficient for immunity to be restored, although growth 


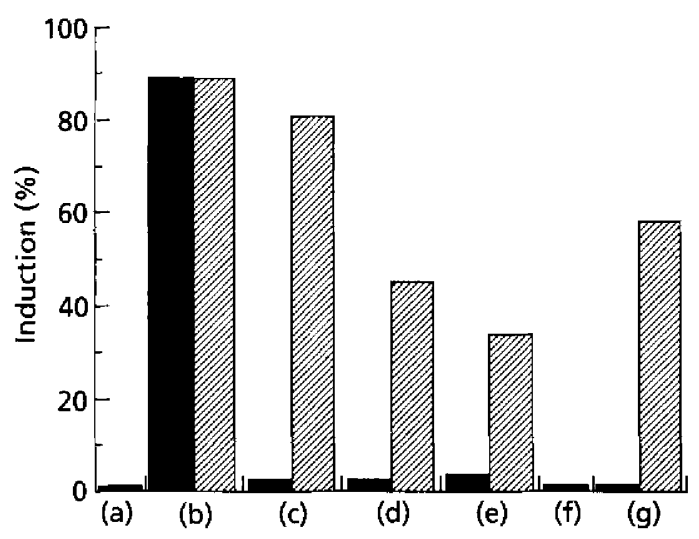

Fig. 3. Induction of immunity in FI5876 and Nis derivatives. (a) MG1614; (b) FI5876; (c) FI7847; (d) FI7300; (e) FI7990; (f) $\mathrm{Fl} 8510$; (g) F18540. Cultures that had been preincubated with $100 \mathrm{ng}$ nisin $\mathrm{ml}^{-1}$ (hatched boxes) and the equivalent untreated cultures (filled boxes) were assayed in microtitre plates for nisin immunity. $O D_{600}$ values were taken when cultures grown in GM17 broth in the absence of nisin had reached maximum cell density. Induction, expressed as a percentage, is a measure of growth in the presence of nisin $\left(2 \mu \mathrm{g} \mathrm{ml}^{-1}\right)$, relative to growth in the absence of nisin. Values represent the mean of three experiments with standard errors less than $20 \%$.

in $2 \mu \mathrm{g}$ nisin $\mathrm{ml}^{-1}$ was significantly slower (growth peaked approximately $2 \mathrm{~h}$ later) than that of cultures induced with $100 \mathrm{ng} \mathrm{m}^{-1}$ (Fig. 2c).

To test whether this induction phenomenon was reversible, FI 7847 cells that had been pretreated with nisin were washed and used to inoculate fresh GM17 broth. After approximately 10 generations growth in the absence of nisin the cells were assayed and immunity was found to be comparable to that of cells which were not pre-exposed to nisin (Fig. 2b).

\section{Induction of immunity in Nis strains}

Cultures of the nisin-producing strain FI5876 and its Nis ${ }^{-}$ derivatives (Fig. 1) were assayed for immunity to nisin and their ability to have immunity restored by induction was investigated. Strains FI7300 and FI7990 have suffered mutations to the nis $A$ gene that respectively introduced a transcription terminator or deletion of the upstream promoter (Fig. 1b, c). Both mutations are likely to affect expression of genes downstream of nis $A$. Plate assays indicated that these mutations had rendered the cells more sensitive than FI7847 to nisin (immunity to nisin $10 \%$ wild-type level) and induction of immunity to nisin was also found to be less effective. Under induction conditions which restored complete immunity to FI7847 (Fig. 3c), both FI7300 and FI7990 displayed sensitivity to nisin (Fig. 3d, e).

\section{Role of NisR in induction of immunity}

To test the role of the two-component regulatory system in immunity to nisin, a derivative of FI7847 (Fig. 1d) was generated that lacked the nis $\mathrm{R}$ gene. The effect of this
Table 1. induction of immunity by nisin fragments

Cultures were preincubated with the inducing agent at either 30 or $300 \mathrm{nM}$ and assayed for nisin immunity in microtitre plates. Molar concentrations were used to ensure that, when dealing with small fragments of nisin, a comparison of induction capacity could be made between the equivalent number of molecules ( $30 \mathrm{nM}$ nisin is approximately $100 \mathrm{ng} \mathrm{ml}^{-1}$ ). Immunity was determined by growth of cultures in the presence of $2 \mu \mathrm{g}$ nisin $\mathrm{ml}^{-1}$ relative to growth in the absence of nisin, and is expressed as a percentage.

\begin{tabular}{|c|c|c|c|}
\hline \multirow[t]{2}{*}{$\begin{array}{l}\text { Inducing agent } \\
\text { (nisin fragment) }\end{array}$} & \multicolumn{2}{|c|}{$\begin{array}{l}\text { Immunity with } \\
\text { inducing agent at: }\end{array}$} & \multirow[t]{2}{*}{$\begin{array}{l}\text { Lanthionine } \\
\text { rings }\end{array}$} \\
\hline & $30 \mathrm{nM}$ & $300 \mathrm{nM}$ & \\
\hline $\operatorname{Nisin}_{1-34}$ (wild-type) & 100 & 98 & $A B C D E$ \\
\hline $\operatorname{Nisin}_{1-\mathbf{3 2}}$ & 98 & 97 & $\mathrm{ABCDE}$ \\
\hline Nisin $_{1-20}$ & 3 & 108 & $\mathrm{ABC}$ \\
\hline $\operatorname{Nisin}_{1-12}$ & 1 & 9 & $A B$ \\
\hline (des-Dha5) Nisin $1-32$ & 1 & 5 & BCDE \\
\hline Pre-nisin leader & 1 & 3 & - \\
\hline
\end{tabular}

mutation, in strain FI8510 (Fig. 1e), was tested by assaying for immunity to nisin. FI8510 ( $\mathrm{Nis}^{-} \mathrm{NisR}^{-}$) displayed a negligible level of immunity (Fig. 3f) comparable to that of the non-nisin-producing strain MG1614 (Fig. 3a). As with MG1614, the sensitivity of FI8510 was such that it did not grow in the presence of inducing levels of nisin. Hence, the ability to induce immunity was lost as a result of the deletion of nis $R$.

The nisR gene and upstream promoter region of FI5876 were cloned into the lactococcal vector pTG262, generating pFI1002. The ability of the plasmid-encoded gene to complement the $\mathrm{NisR}^{-}$deficiency in FI8510 was tested by transforming this strain with pFI1002. The resulting strain, designated FI8540, was able to respond to induction with nisin. The induced strain had recovered immunity, although not to the same level as that of the parental strain FI7847 (Fig. 3g).

\section{Structural requirements of inducing agents}

Using nisin immunity as an indicator of induction, the effectiveness of various derivatives of nisin as inducing agents was investigated. The nisin fragments tested were all able to induce immunity in FI7847, but with the smaller fragments the level of immunity was significantly lower (Table 1). When equimolar concentrations of nisin fragments were used it was evident that, at $30 \mathrm{nM}$ ( $=100 \mathrm{ng}$ nisin $\mathrm{A} \mathrm{ml}^{-1}$ ), the minimum requirement for

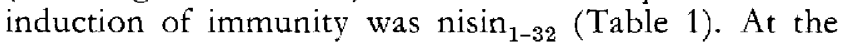
higher concentration of $300 \mathrm{nM}$, the nisin fragment nisin $_{1-20}$ was as effective at restoring immunity as the complete molecule (Table 1). Nisin ${ }_{1-12}$ did not function as an inducing agent until a concentration of $600 \mathrm{nM}$ was used. The only difference between nisinn ${ }_{1-32}$ and (des$\Delta$ Ala5)nisin ${ }_{12}$ is cleavage of ring A (Chan t al., 1989) in 


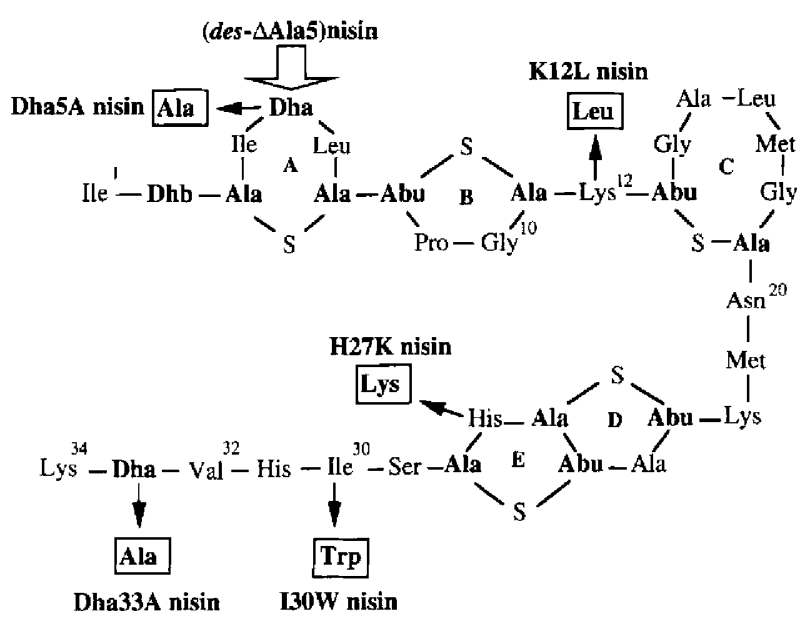

Fig. 4. Molecular structure of nisin and nisin variants. Amino acid substitutions, in different engineered molecules, are indicated by arrows to boxes. The large arrow in ring A indicates the position at which cleavage occurs to generate (des- $\Delta$ Ala5) nisin.

the latter nisin derivative (Fig. 4). However, while nisin $_{132}$ functions effectively as an inducing agent, the ability of (des- $\triangle A$ la5) nisin 1-32 to restore immunity in strain FI7847 has been abolished (Table 1). The leader peptide was also unable to induce immunity at any of the concentrations tested.

All the engineered peptides displayed the ability to induce nisin immunity in FI7847, although to varying degrees (Table 2). The alteration to ring $A$ in Dha5 $A$ nisin $A$ (Fig. 4) did not appear to adversely affect induction. In contrast, the substitution of a Dha for an alanine at position 33 in Dha33A nisin $A$ and Dha5,33A nisin $A$ had the effect of

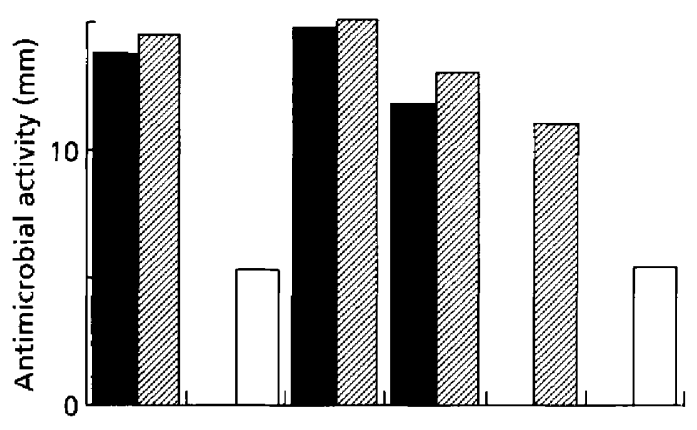

Immunity...

+++ +++

(b)

(c)

(d)

(e)

(f)

Fig. 5. Effect of induction on immunity and production in strains producing engineered nisins. (a) FI5876; (b) FI7990; (c) Fl8327; (d) Fl8256; (e) Fl8278; (f) Fl8290. Antimicrobial activity is expressed as the diameter ( $\mathrm{mm})$ of the zone of inhibition (after subtracting the size of the well) of the indicator organism in plate bioassays. Samples from untreated cultures are shown as solid bars and the hatched bars represent samples from cultures that have been preincubated with nisin $\left(100 \mathrm{ng} \mathrm{ml}^{-1}\right)$. The open boxes indicate where a small zone of inhibition was generated due to the nisin in the broth $\left(100 \mathrm{ng} \mathrm{ml}^{-1}\right)$ included in the incubation. These samples, from strains FI7990 (b) and FI8290 ( $f$ ), do not produce any additional antimicrobial activity as a result of the induction. Immunity was determined in plate assays on $\mathrm{GM} 17$ agar containing $20 \mu \mathrm{g}$ nisin $\mathrm{ml}^{-1}$. Immunity was expressed in terms of the amount of growth relative to the wild-type strain F15876. +++ . Confluent growth;,$++>10$ colonies;,$+<10$ colonies; - , no growth.

significantly lowering the induction capacity of the molecules. This was restored by increasing the concentration of the molecules 10 -fold. K12L nisin A, H27K nisin A and I30W nisin A (Fig. 5) were able to induce

Table 2. Induction of immunity by nisin and engineered nisin variants

\begin{tabular}{|c|c|c|c|c|}
\hline \multirow[t]{2}{*}{ Strain } & \multirow[t]{2}{*}{$\begin{array}{l}\text { Inducing agent } \\
\text { (nisin variant) }\end{array}$} & \multicolumn{2}{|c|}{$\begin{array}{l}\text { Immunity* with inducing } \\
\text { agent at: }\end{array}$} & \multirow[t]{2}{*}{$\begin{array}{c}\text { Activity } \\
(\%) \dagger\end{array}$} \\
\hline & & $100 \mathrm{ng} \mathrm{ml}^{-1}$ & $1 \mu \mathrm{g} \mathrm{ml}^{-1}$ & \\
\hline MG1614 & - & 2 & 4 & - \\
\hline FI5876 & - & 94 & 100 & - \\
\hline FI7847 & - & 3 & 3 & - \\
\hline FI 7847 & A (wild-type) & 104 & 104 & 100 \\
\hline FI7847 & Dha.5A & 114 & 107 & 52 \\
\hline $\mathrm{F}[7847$ & Dha33A & 17 & 101 & 52 \\
\hline FI7847 & Dha5,33A & 34 & 106 & 13 \\
\hline FI784? & $\mathrm{H} 27 \mathrm{~K}$ & 86 & ND & 100 \\
\hline FI7847 & $\mathrm{K} 12 \mathrm{~L}$ & 81 & ND & 100 \\
\hline FI7847 & $\mathrm{I} 30 \mathrm{~W}$ & 41 & ND & 81 \\
\hline
\end{tabular}

ND, Not determined.

* Cultures were preincubated with the inducing agent at a concentration of either $100 \mathrm{ng} \mathrm{ml}^{-1}$ or $1 \mu \mathrm{g} \mathrm{mi}^{-1}$ and assayed for nisin immunity in microtitre plates (see legend to Table 1).

$\lceil$ Activity against L. lactis MG1614 (Gasson, 1983), relative to nisin A, was determined from minimum inhibitory concentrations. The value for nisin $\mathrm{A}\left(0 \cdot 13 \mu \mathrm{g} \mathrm{ml}^{-1}\right)$ was taken as $100 \%$ (Dodd $e t$ al., 1996). 
immunity, although to a lesser degree than the wild-type molecule (Table 2).

\section{Induction of immunity in strains producing nisin variants}

The effect of induction in strains producing variant nisins was investigated. Immunity of cells that had been preincubated with nisin was determined and compared to that of the equivalent untreated cultures in plate assays. The Nis $A^{-}$strain FI7990 had significantly teduced immunity (Dodd et al., 1996) and this could not be testored by induction (Fig. 5b). With derivative strains encoding a variant nis $A$ gene, immunity had been affected to varying extents; however, in all cases, full immunity was restored in response to preincubation with nisin (Fig. $5 c, d)$. A negligible inctease in the production of antimicrobial activity, as a result of nisin induction, was evident in the parent strain FI5876 and the derivatives FI8327 and FI8256 (Fig. 5a, c, d). In the case of the nisin variant produced by FI8278, this yield increase was more striking. With no nisin induction, inhibition was not detected in bioassays. However, after preincubating the cells with nisin, antimicrobial activity in the supernatant sample had significantly increased (Fig, 5e). Pretreatment of FI 8290 cells with nisin did not result in the production of antimicrobial activity. This engineered strain, encoding the variant gene nis $A / \Delta 21 \mathrm{M}$, did, however, display intermediate levels of immunity and recovered full immunity in response to induction.

\section{DISCUSSION}

Autoregulation of nisin biosynthesis has recently been described with the demonstration of inducible nis $A$ transcription in response to extracellular nisin (Kuipers $e t$ al., 1995). Here we have shown that self-immunity of the nisin-producing strain FI5876 is also subject to nisin induction. This phenomenon would not normally be apparent as nisin-producing cells would be expected to be in a perpetual state of induction with continual production and immunity to nisin. Using the $\mathrm{Nis}^{-}$strain FI7847, it was possible to investigate the effect of nisin induction on the immunity function in the absence of nisin production. The nisin promoter of FI7847 is unaffected by the frameshift mutation suffered by the nis $A$ gene (Fig. 1d) and expression of downstream genes would be expected to occur as a result of transcriptional readthrough. With this strain, it was possible to demonstrate that immunity to nisin could be restored to the level of the $\mathrm{Nis}^{+}$parent strain, as a result of induction with subinhibitory levels of nisin. Induction is a reversible phenomenon and the elevated immunity level was lost if the inducing agent was removed from the external environment. Cells reverted to the untreated state and were as sensitive as cells that have not been pre-exposed to nisin.

Kuipers et al. (1995) demonstrated that expression of the adjacent $n i s B$ gene is under the same autoregulation as $n i s$, , with both being dependent on the presence of the upstream nis $A$ promoter. From the work presented here, the number of genes in the cluster that are subject to the same autoregulation can be extended to include those involved in self-immunity, the most likely candidate being nisI (Kuipers et al., 1993; Engelke et al., 1994; Qiao et al., 1995). This suggests that coexpression of this gene and nis $A$, along with the intervening nis $B$, nis $T$ and nis $C$ genes (Fig. 1), occurs in response to induction with nisin. The absence of a transcription terminator at the end of nisI and lack of a convincing promoter for nis $P$ argues that the complete polycistronic transcriptional unit, controlled by the inducible nis $A$ promoter, includes six genes and extends from nis $A$ to $n i s P$. If transcription is prevented, due to deletion of the promoter (in the case of FI7990; Fig. 1c) or by introduction of a transcriptional terminator in nis $A$ (in the case of FI7300; Fig. 1b), induction is impeded and immunity levels are reduced (Fig. 3). This is consistent with the proposal that genes within this transcriptional unit are involved in immunity. It was interesting to note that induction in these latter two strains is not completely abolished. The level of immunity displayed by these strains, approximately $40 \%$ of the parental strain (Fig. 3d, e), may be explained by limited transcriptional readthrough to the downstream genes including nisI. An alternative interpretation is that another gene(s), outside the putative nis $A-n i s P$ operon, is involved in immunity, as proposed by Qiao et al. (1995). It has been suggested that the nis $F$, nis $E$ and nis $G$ genes fulfil this role (Siegers \& Entian, 1995). Furthermore, it has recently been reported that the expression of these three genes is under the control of an inducible promoter that responds to nisin in the external environment $(O . P$. Kuipers and others, personal communication). While further transcriptional analysis of the different cistrons is required, it can be speculated that, in the absence of a NisI function, an alternative immunity mechanism may exist that supplies a lower level of protection to the host cell.

The amount of inducing agent present in the external environment affects the ievel of immunity. It was only possible to detect induction of immunity with nisin at $10 \mathrm{ng} \mathrm{ml}^{-1}$ ( $3 \mathrm{nM}$ ) or above. This concentration is 100 fold higher than that reported by Kuipers et al. (1995) for induction of transcription of the nis $A$ gene. They found a reduction $(\sim 50$-fold) in the level of transcription of sequences downstream of nis $A$ and this was attributed to the presence of a large inverted repeat in the intergenic region between nis $A$ and nisB. The function of this putative hairpin-loop structure may be to limit transcriptional readthrough to the genes downstream of nis $A$, which could account for the observed requirement for higher levels of the inducing agent to bring about full immunity.

An investigation of the role of the two-component regulatory system in nisin induction involved the construction of a strain that lacked the nis $\mathrm{R}$ gene, as well as containing a defective nis $A$ gene. Nisin immunity in this strain, FI8510 (Fig. 1e), had effectively been abolished as a result of the chromosomal mutations. Its sensitivity was significantly higher than that of strains with reduced immunity due to impaired transcription, i.e. FI7847, FI7300 and FI7990 (Fig. 4). Unlike in these latter strains, it did not prove possible to elevate the levels of immunity 
in FI8510 by induction with nisin (Fig. 3). Complementation of the deficiency by provision of a plasmidencoded nis $\mathrm{R}$ gene restored an inducible immunity phenotype in strain FI8540 (Fig. 3). This is consistent with NisR acting as a response regulator necessary for activating transcription of the immunity determinants. The lower immunity level displayed by FI8540 may be due to the fact that the nis $\mathrm{R}$ gene is encoded by a multicopy plasmid rather than being cotranscribed with the chromosomal nisK gene. It has been demonstrated that NisK is an essential component of the nisin regulatory mechanism. Kuipers et al. (1995) created a NisK ${ }^{-}$strain in which transcription was not induced by external nisin. The results presented here complement these findings and underline the vital role of the two-component regulatory system in the autoregulation of nisin biosynthesis and immunity.

To identify which regions of nisin are required for induction, the capacity of a range of structural variants to function as inducers of immunity was assessed. Analysis of enzymically generated nisin fragments demonstrated that all five rings of the processed nisin molecule were necessary for efficient induction of immunity, although the 12 amino-terminal residues (rings $A$ and $B$ ) were sufficient if the concentration was increased 20 -fold (Table 1). A significant finding was that when ring $A$ was broken in [des-Dha5]nisin ${ }_{1-32}$, induction was abolished (Table 1). The opening of this ring (Fig. 4) would cause an increase in the flexibility of the molecule and radically change the conformation of this region of nisin (Chan et al., 1989). This suggests that ring $A$ plays a major role in the molecular interactions between the inducing agent (nisin) and the membrane-located sensor protein NisK. An alteration to the constituent amino acids in ring $\mathrm{A}$ is not likely to have such an extreme effect on its conformation. The substitution of Dha for an Ala in the variant Dha5A nisin A simply results in loss of a double bond and an additional hydrogen at position 5 (Chan $e t$ al., 1989). The biological activity of this engineered nisin was only slightly lower than that of nisin A (Dodd et al., 1996) and its ability to function as an inducer of immunity was unaffected by the introduced changes (Table 2). Interestingly, amino acid changes made in other regions of nisin, including the carboxy-terminal tail, resulted in a reduction in the capacity of the molecule to induce immunity. The induction capacity of both Dha33A nisin and I $30 \mathrm{~W}$ nisin was less than $50 \%$ of that of the wild-type molecule (Table 2). It may be that overall conformational changes brought about by these mutations influence the binding properties of the molecule. The reduced efficiency of interaction between the inducing agent and the receptor molecule couid be overcome by supplying the signal peptide at a higher concentration (Table 2). In similar work reported by Kuipers et al. (1995), it was also found that the amino-terminal region of the molecule $\left(\right.$ nisin $\left._{111}\right)$ was important for induction. From both studies, it was apparent that the ability of a nisin variant to act as an inducer of biosynthesis and immunity was not directly related to its specific activity against $L$. lactis MG1614 (Table 2). This suggests that antimicrobial interactions with the membrane of sensitive cells resulting in pore formation (Giffard et al., 1996; Abee, 1995; Gao et al., 1991; Sahl, 1991) are distinct from the signal peptide/ membrane sensor interactions that lead to induction of biosynthesis and immunity.

Increased knowledge of the role of induction in biosynthesis and immunity is of value in the exploitation of lactococcal expression systems based on genetic adaptation of the nisin operon (Dodd et al., 1992, 1995, 1996). Bioassays of cell-free extracts demonstrate that peptide yields can vary considerably between different nisin variants, regardless of their specific activity. This can be attributed to variation in the induction capacity of the different engineered nisins. The biosynthesis of $\mathrm{I} 30 \mathrm{~W}$ nisin A by strain FI8278 is a good example of how poor induction by the engineered molecule (Table 2) results in very low levels of production. However, by adding subinhibitory levels of nisin to the growth media, immunity increased and, with it, the ability to produce significantly higher quantities of the modified peptide (Fig. 5e). The specific activity of the purified peptide was not much lower than that of the wild-type molecule, but its capacity to function as an inducer was considerably reduced (Table 2). Those strains which produce a nisin variant that functions efficiently as an inducer (e.g. FI8327 producing $\mathrm{H} 27 \mathrm{~K}$ nisin $\mathrm{A}$ ) behave in a similar manner to FI5876. The strains are fully immune to nisin and production of antimicrobial activity is effectively at its maximum level (Fig. 5a, c). It was interesting to note that, while FI8290 (encoding nis $A / \Delta 21 \mathrm{M}$ ) did not generate any detectable antimicrobial activity, its immunity to nisin was above background level and, significantly, was found to be higher than that of FI8278 (Fig. 5e, f). This suggests that the nisin operon in FI8290 is expressed, resulting in the production and secretion of a processed $\Delta 21 \mathrm{M}$ nisin $\mathrm{A}$ molecule. Furthermore, this shortened peptide, although not as efficient as nisin, retains its ability to act as an inducing agent. Such a molecule, lacking biological activity, may be of use in the development of lactococcal production systems in which the inducible nis $A$ promoter is employed for the expression of heterologous peptides and proteins. The absence of biological activity by the inducing agent means that such an expression system need not involve any of the nisin immunity functions. A closely related line of work involves protein engineering the nisin molecule using lactococcal expression systems (Dodd $e t$ al., 1995, 1996). The results reported here demonstrate that production levels of variant nisins can also benefit from induction, ensuring that the potential of the expression systems extends to the generation of those variant molecules that do not efficiently autoregulate their own biosynthesis.

\section{REFERENCES}

Abee, T. (1995). Pore-forming bacteriocins of gram-positive bacteria and self-protection mechanisms of producer organisms. FEMS Microbiol Leit 129, 1-10.

Casadaban, M. J. \& Cohen, S. N. (1980). Analysis of gene control signals by DNA fusion and cloning in Escherichia coli. J Mol Biol 138, $179-207$. 
Chan, W. C., Bycroft, B. W., Lian, L.-Y. \& Roberts, G. C. K. (1989). Isolation and characterization of two degradation products derived from the peptide antibiotic nisin. FEBS Lett 252, 29-36.

Chan, W. C., Leyland, M., Clarke, J., Dodd, H. M., Lian, L.-Y., Gasson, M. J., Bycroft, B. W. \& Roberts, G. C. K. (1996). Structureactivity relationships in the peptide antibiotic nisin: antibacterial activity of fragments of nisin. FEBS Lett (in press).

Dodd, H. M., Horn, N. \& Gasson, M. J. (1990). Analysis of the genetic determinant for the peptide antibiotic nisin. $J$ Gen Microbiol 136, 555-566.

Dodd, H. M., Horn, N., Zhang, H. \& Gasson, M. J. (1992). A lactococcal expression system for engineered nisins. Appi Environ Microbiol 58, 3683-3693.

Dodd, H. M., Horn, N. \& Gasson, M. J. (1995). A cassette vector for protein engineering the lantibiotic nisin. Gene 162, 163-164.

Dodd, H. M., Horn, N., Giffard, C. J. \& Gasson, M. J. (1996). A gene replacement strategy for engineering nisin. Microbiology 142, 47-55.

Engelke, G., Gutowski-Eckel, Z., Kiesau, P., Siegers, K., Hammelmann, M. \& Entian, K.-D. (1994). Regulation of nisin biosynthesis and immunity in Lactococcus lactis 6F3. Appl Environ Microbiol 60, 814.825 .

Gao, F. H., Abee, T. \& Konings, W. N. (1991). Mechanism of action of the peptide antibiotic nisin in liposomes and cytochrome $c$ oxidase-containing proteoliposomes. Appl Entiron Microbial 57, 2164-2170.

Gasson, M. J. (1983). Plasmid components of Streptococcus lactis VCDO 712 and other lactic streptococci after protoplast-induced curing. J Bacteriol 154, 1-9.

Giffard, C. J., Ladha, S., Mackie, A. R., Clark, D. C. \& Sanders, D. (1996). Interaction of nisin with planar lipid bilayers monitored by fluorescent recovery after photobleaching. I Membr Biol 151, 293-300.

Horinouchi, S. \& Weisblum, B. (1982). Nucleotide sequence and functional map of $\mathrm{pE} 194$, a plasmid that specifies inducible resistance to macrolide, lincosamide and streptogramin type $B$ antibiotics. J Bacteriol 150, 804-814.
Kuipers, O. P., Beerthuyzen, M. M.s Siezen, R. J. \& de Vos, W. M. (1993). Characterization of the nisin gene cluster nis $A B T C I P R$ of Lactococcus lactis. Eur J Biochem 216, 281-291.

Kuipers, O.P., Beerthuyzen, M. M., de Ruyter, P. G. G. A., Luesink, E. J. \& de Vos, W. M. (1995). Autoregulation of nisin biosynthesis in Lactococtus lactis by signal transduction. J Biol Chem 270, 27299-27304.

Lennox, E. S. (1955). Transduction of linked genetic characters of the host bacteriophage P1. Virology 1, 190-206.

Qiao, M. Q., Immonen, T., Koponen, O. \& Saris, P. E. J. (1995). The cellular location and effect on nisin immunity of the NisI protein from Lactococcus lactis N8 expressed in Escherichia coli and L. lactis. FEMS Microbiol Lett 131, 75-80.

Sahl, H.-G. (1991). Pore formation in bacterial membranes by cationic lantibiotics. In Nisin and Novel Lantibiotics, pP. 347385. Edited by G. Jung \& H.-G. Sahl. Leiden: ESCOM.

Siegers, K. \& Entian, K. D. (1995). Genes involved in immunity to the lantibiotic nisin produced by Lactococcus lactis 6F3. Appl Environ Micrabiol 61, 1082-1089.

Terzaghi, B. E. \& Sandine, W. E. (1975). Improved medium for lactic streptococci and their bacteriophages. Appl Environ Microbiol $29,807-813$.

Tramer, J. \& Fowler, G. G. (1964). Estimation of nisin in foods. I $S c i$ Food Agrii 15, 522-528.

Van der Meer, J. R., Polman, J., Beerthuyzen, M. M., Siezen, R. J.s Kuipers, O.P. \& de Vos, W. M. (1993). Characterization of the Lactococcus lactis nisin-A operon genes nisP, encoding a subtilisinlike serine protease involved in precursor processing, and nis $\mathrm{R}$, encoding a regulatory protein involved in nisin biosynthesis. I Bacteriol 175, 2578-2588.

Wanner, B. L. (1992). Is cross regulation by phosphorylation of two-component response regulator proteins important in hacteria? J Bacteriol 174, 2053-2058.

Received 6 March 1996; revised 7 May 1996; accepted 13 May 1996. 